\title{
ARE OPOSSUMS CAPABLE OF TRANSMITTING LEPTOSPIROSIS IN URBAN
} AREAS?

\section{Lucheis SB (1), Hernandes GS (2), Lenharo DK (3), Santiago MEB (4), Baldini- Peruca LC (5)}

(1) São Paulo Agency of Agribusiness Technology, APTA, Bauru, São Paulo State, Brazil; (2) Biology Intern Program, São Paulo Agency of Agribusiness Technology, APTA, Bauru, São Paulo State, Brazil; (3) Department of Biological Sciences, Sacred Heart University, Bauru, São Paulo State, Brazil; (4) Veterinarian of the Municipal Zoological Garden, Bauru, São Paulo State, Brazil; (5) Graduation Program in Veterinary Medicine, Veterinary Medicine and Animal Husbandry School, São Paulo State University, UNESP, Botucatu, São Paulo State, Brazil.

Dear Editor:

Among the zoonotic illnesses, one of the most common examples is leptospirosis, a general denomination for a group of acute or chronic infections and contagious diseases, clinically multiform, caused by Leptospira interrogans (1). According to their virulence and pathogenicity, these leptospires, however, may provoke infections in other mammals, such as dogs and humans that become accidental hosts (2). In Brazil, epidemiological studies on wild animal infections are rare (3). Rodents and marsupials, including opossums, are considered the most important leptospirosis reservoirs (4).

Opossums are omnivorous mammals that belong to the Marsupialia order and are widespread in the South America. They present crepuscular and night habits and due to their opportunistic behavior, these animals are well adapted to numerous environments. Opossums are synanthropic animals that may live among humans both in rural and urban areas - where they are more and more commonly found on account of the availability of water, shelter and food. This characteristic makes them significant disseminators of diseases among wild and domestic animals as well as 
humans (5). Besides their great role in Chagas disease etiology, opossums may transmit other infections such as leptospirosis through their urine.

Thirty-nine opossums of the species Didelphis albiventris were captured in different places of the Bauru urban area, São Paulo state, Brazil. Their sera were submitted to microscopic agglutination test (MAT) for leptospirosis, according to Ministry of Health procedures at the Animal Health Laboratory of APTA, in Bauru (6). The Copenhageni antigen (11A) was the most prevalent, found in 32 opossums (82\%), followed by Patoc (64.1\%); Cynopteri (53.8\%); Hardjoprajitno (46.2\%); Bratislava (41\%); Hebdomadis (25.6\%); Icterohaemorrhagiae, Pyrogenes and HardjoCTG (23.1\%); Hardjo, Wolffi and Andamana (17.9\%); Australis, Djasiman, Javanica, Panama and Hardjobovis (12.8\%); Sentot (12.3\%); Autumnalis, Bataviae, Whitmanni, Grippotyphosa and Mini (7.7\%); Butembo, Castellonis, Canicola and Tarassovi (5.1\%) and Shermani (2.6\%). The Pomona serovar did not react with any of the tested sera.

Among synanthropic animals, the serovar Copenhageni is known as an important leptospirosis infection source and is responsible for maintaining the agent and giving rise to the infection in humans and other animals (1). The persistence of leptospirosis transmission is aggravated by the presence in urban environments of synanthropic rodents and marsupials such as opossums. Because of ecological imbalance, animals that used to live in equilibrium with their natural environments are now moving to urban areas seeking shelter and food. Thus, they are easily found in cities due to the presence of garbage and environmental disturbances. This situation favors the dissemination of zoonoses like leptospirosis, Chagas disease and leishmaniasis $(7,8)$.

The prevention of leptospirosis should be based on the eradication of reservoir rodents that may infect humans and other animals. Removal of organic garbage, food waste and refuse materials that may shelter rodents and opossums are the primary measure to control the transmission. Additionally, stationary water and contact with sewage must be avoided in all urban areas. Therefore, a substantial investment in basic sanitation is required (9). The high frequency and serological reactions to Copenhageni serovar demonstrate that this leptospira is persisting in the environment, probably because of the continuing presence of rodents in urban areas, which enables transmission of this agent to opossums. The elevated percentage of serovars reactive to tested samples reveals the infectivity degree to which these 
animals were exposed. New studies to assess the infection degrees by leptospires in opossums are necessary, due to the importance that these animals have assumed in leptospirosis epidemiology on account of ecological imbalance.

\section{CORRESPONDENCE TO:}

SIMONE BALDINI LUCHEIS, Departamento de Descentralização do Desenvolvimento, Agência Paulista de Tecnologia dos Agronegócios, APTA, Unidade de Pesquisa de Bauru, Pólo Centro-Oeste, Av. Rodrigues Alves, 40-40, Horto Florestal, Bauru, SP, 17030-000, Brasil. Phone: +55 143203 3257. Fax: +55 143281 4391. Email: silucheis@apta.sp.gov.br.

\section{REFERENCES}

1. Corrêa WM, Corrêa CNM. Leptospiroses. In: Enfermidades infecciosas dos mamíferos domésticos. Rio de Janeiro: Medsi; 1992. p. 219-31.

2. Levett PN. Leptospirosis. Clin Microbiol Rev. 2001;14(2):296-326.

3. Girio RJS, Herrera RCP, Pereira FJG, Mathias LA. Pesquisa de infecção por Leptospira interrogans em animais da região de Nhecolândia, no Pantanal do Mato Grosso do Sul. Arq Inst Biol. 1999;65:87(suppl).

4. Faine S, Adler B, Bolin C, Perolat P. Leptospira and leptospirosis. $2^{\text {nd }}$ ed. Melbourne: Med Sci; 1999. 272 p.

5. Muller G, Brum JGW, Langoni PQ, Michels GH, Sinkoc AL, Ruas JL. Didelphis albiventris lund 1841, parasitado por Ixodes loricatus Neumann, 1899 e Amblyoma aureolatum (Pallas, 1772) (Acari Ixodidae) no Rio Grande do Sul. Arq Inst Biol. 2005;72(3):319-24.

6. Brasil. Ministério da Saúde. Fundação Nacional da Saúde. Centro Nacional de Epidemiologia. Coordenação de Controle de Zoonoses e Animais Peçonhentos. Manual de Leptospirose. Brasília: Fundação Nacional de Saúde; 1995. 98 p.

7. Lucheis SB, Da Silva AV, Araújo Jr. JP, Langoni H, Meira DA, MarcondesMachado J. Trypanosomatids in dogs belonging to individuals with chronic Chagas disease living in Botucatu town and surrounding region, São Paulo State, Brazil. J Venom Anim Toxins incl Trop Dis. 2005;11(4):492-509. 
8.Santiago MAB, Vasconcelos RO, Fattori KR, Munari DP, Michelin AF, Lima VMF. An investigation of Leishmania spp. in Didelphis spp. from urban and periurban areas in Bauru (São Paulo, Brazil). Vet Parasitol. 2007;150(4):283-90.

9. Vianna MSR. Vigilância em saúde na cidade do Rio de Janeiro. SMG-RIO SCZ Boletim de Divulgação Técnica e Científica. 2001. Available from: http://www.ccs.saude.gov.br/visa/publicacoes/arquivos/bol11.pdf. 